\title{
PENGEMBANGAN BAHAN AJAR "SMART CARD" PADA MATERI PECAHAN SENILAI UNTUK MENINGKATKAN PEMAHAMAN SISWA SMPI ZAINAL ABIDIN
}

\author{
Moh. Khoirul Anam ${ }^{1}$, Riska Nur Yunita Sari ${ }^{2}$ \\ STIA Bayuangga Probolingg ${ }^{1,2}$ \\ khoirulanam30101992@gmail.com
}

\begin{abstract}
Abstrak
Penelitian ini merupakan penelitian pengembangan yang bertujuan untuk menciptakan suatu karya inovasi berupa Kartu Pintar "Smart Card” untuk membantu Siswa dalam memahami materi perbandingan pecahan senilai serta menumbuhkan pembelajaran yang lebih menantang dan menyenangkan bagi Siswa. Penelitian ini dapat digolongkan dalam penelitian pengembangan yang berfokus untuk menghasilkan sebuah karya inovasi yang dapat membantu siswa dan guru dalam suatu proses belajar mengajar. Penggunaan media dapat membuat Siswa lebih aktif dalam proses pembelajaran sehingga Siswa dapat mengembangkan kreatifitas dan inovasinya. Penggunaan media pembelajaran dapat dilakukan pada berbagai materi yang akan di ajarkan di dalam kelas. Salah satu materinya yaitu materi bilangan yang ada pada kelas VII sekolah menengah pertama. Materi ini merupakan materi pembuka bagi Siswa yang ada di kelas VII. Adapun hasil dari penelitian pengembangan ini adalah 1) Karya Inovasi ini memiliki sedikit kesulitan dalam pembuatan desain, 2) Media ini tidak memerlukan listrik ataupun alat elektronik yang serba canggih sehingga dapat diterapkan di lembaga mana saja dan kapan saja, 3) Siswa merasa sangat semangat, senang, dan termotivasi ketika pembelajaran menggunakan media Smart Card, 4) Guru dapat menyampaikan pesan pembelajaran secara utuh serta Siswa merasa tertarik, tertantang, dan termotivasi pada permainan Smart Card ketika saat proses pembelajaran berlangsung.
\end{abstract}

Kata Kunci: Kartu Pintar, Karya Inovasi, dan Media Pembelajaran

\begin{abstract}
This research is a research development that aims to create an innovative work in the form of a Smart Card "Smart Card" to assist students in understanding material comparative fractions worth and foster learning that is more challenging and enjoyable for students. This research can be classified in development research that focuses on producing an innovative work that can help students and teachers in a teaching and learning process. The use of media can make students more active in the learning process so that students can develop their creativity and innovation. The use of instructional media can be done on a variety of materials that will be taught in the classroom. One of the material is number material in grade VII junior high school. This material is an opening material for students in class VII.

The results of this development research are 1) This innovation work has a little difficulty in making designs, 2) This media does not require electricity or sophisticated electronic equipment so it can be applied at any institution and at any time, 3) Students feel very excited, happy, and motivated when learning using Smart Card media, 4) Teachers can convey the message of learning as a whole and students feel interested, challenged, and motivated in the Smart Card game when the learning process takes place.
\end{abstract}

Keywords: Smart Cards, Innovation Work, and Learning Media 


\section{PENDAHULUAN}

Guruan merupakan usaha yang sudah direncanakan sebelumnya untuk membuat proses belajar mengajar antara guru dan siswa agar siswa dapat mengelurkan potensi yang dimilikinya, seperti kekuatan spiritual keagamaan, pengendalian diri, kepribadian, kecerdasan, akhlak mulia, serta keterampilan yang diperlukan dirinya, masyarakat, bangsa dan Negara. Proses Pembelajaran pada satuan Guruan diselenggarakan secara interaktif, inspiratif, menyenangkan, menantang, memotivasi pesertadidik untuk berpartisipasi aktif, serta memberikan ruang yang cukup bagi prakarsa, kreativitas, dan kemandirian sesuai dengan bakat, minat, dan perkembangan fisik serta psikologis siswa [1][2].

Seorang Guru harus mempunyai suatu keterampilan dan pemahaman mengenai makna belajar dengan segala bentuk perwujudannya seperti ide, konsep, pemikiran, dan lainnya. Guru harus siap dan mampu setiap saat dalm mempersiapkan dan melakukan proses pembelajaran. Persiapan tersebut meliputi kemampuan Siswa, metode, media, dan strategi yang cocok untuk digunakan dalam proses belajar mengajar siswa. Dalam pembelajaran konvesional, Siswa sering tidak dilibatkan dalam proses KBM. Siswa hanya duduk manis dan mendengarkan penjelasan guru. Guru selalu mendominasi proses belajar mengajar. Proses belajar mengajar seperti ini kurang mengembangkan gagasan, ide, dan kreatifitas siswa.

Salah satu cara yang dapat dipakai oleh guru untuk meningkatkan proses pembelajaran yaitu dengan menggunakan media. Media yang bisa dipakai dalam pembelajaran seperti LCD, Kertas buffalo, dan lain sebagainya. Penggunaan media dapat membuat Siswa lebih aktif dalam proses pembelajaran sehingga Siswa dapat mengembangkan kreatifitas dan inovasinya. Apabila proses pembelajara seperti itu terjadi Siswa pastinya akan lebih berperan aktif dari pada Guru saat proses pembelajaran berlangsung.

Ditinjau dari asal katanya, media/alat peraga Hamalik [3] dan Sudirman [4] berpendapat bahwa media berasal dari bahasa Latin yang terbentuk dari kata medium yang berarti perantara atau pengantar pesan ke penerima pesan. Menurut KBBI [5] media/alat peraga diartikan sebagai alat ( sarana ) komunikasi seperti koran, majalah, radio, televisi, iklan, poster dan spanduk. Media juga berarti perantara / penghubung. Definisi media sangat luas mencakup bahan cetak, rekaman audio dan video, program radio, program televisi, tulisan guru di papan tulis, gambar, gerak-gerik guru. Keseluruhan media tersebut membentuk situasi pembelajaran yang ditandai adanya komunikatif interaktif antara guru dengan sekelompok siswa baik yang berlangsung di dalam maupun di luar kelas. Kemudian Rahadi [6] menjelaskan bahwa media sebagai jenis komponen dalam lingkungan siswa yang dapat merangsang mereka untuk belajar.

Penggunaan media pembelajaran lebih memberikan manfaat yang positif kepada siswa. Hal ini sesuai dengan Rahwanti [7] yang menyatakan bahwa secara umum manfaat alat peraga/media dalam proses belajar mengajar yaitu untuk memperlancar interaksi antara guru dan siswa, sehingga kegiatan belajar mengajar yang terjadi di dalam kelas bias menjadi lebih efisien.

Guru mengembangkan media pembelajaran yang dapat membantu siswa memahami materi pembelajaran dengan efektif, menyenangkan dan dapat memberikan gambaran konkrit bagaimana cara membandingkan pecahan senilai, yaitu dengan menggunakan permainan kartu "Smart Card" dimana cara 
permainannya hampir sama dengan permainan kartu UNO. Permainan kartu UNO sendiri juga berguna sebagai media dalam menentukan permasalahan pada materi matematika. Seperti yang dilakukan oleh Rahwanti [8] yang dalam penelitiannya dia menggunakan permainan kartu UNO untuk meningkatkan kemapuan hitung dasar siswa di sekolah dasar. Pengembangan media dalam penelitian ini berjudul, pengembangan media pembelajaran USH (Uno Stacko Hitung).

Smart Card merupakan suatu permainan yang di buat oleh Guru menggunakan kertas buffalo yang dibuat dan di bentuk menyerupai kartu UNO. Tetapi dengan desain dan cara permainan yang berbeda dari permainan kartu UNO. Permainan Smart Card ini dibuat dengan tujuan untuk menarik semangat siswa sehingga siswa berperan aktif dalam proses pembelajaran.

Media yang digunakan dalam pembelajaran ini berupa kartu permainan yang diberi nama Smart Card. Smart Card merupakan suatu permainan yang di buat oleh Guru menggunakan kertas buffalo yang dibuat dan di bentuk menyerupai kartu UNO. Tetapi dengan desain dan cara permainan yang berbeda dari permainan kartu UNO. Permainan Smart Card ini dibuat dengan tujuan untuk menarik semangat Siswa sehingga Siswa berperan aktif dalam proses pembelajaran. Media ini tidak memerlukan listrik ataupun alat elektronik yang serba canggih. Jadi media ini dapat digunakan oleh sekolah yang minim dalam hal teknologi seperti di SMPI Zainal Abidin. Media belajar berupa Smart card ini belum terlalu di kenal di sekolahsekolah, terlebih di sekolah yang ada di lingkungan Kecamatan Sumberasih.

Sebelum permainan kartu Smart Card ini di mainkan terlebih dahulu guru membentuk kelompok sebanyak 3-4 anak tiap kelompok. Penerapan media pembelajaran Smart Card dalam proses pembelajaran guru hanya menyampaikan aturan dari permainan secara singkat dan jelas kepada siswa.

Penggunaan media pembelajaran dapat dilakukan pada berbagai materi yang akan di ajarkan di dalam kelas. Salah satu materinya yaitu materi bilangan yang ada pada kelas VII sekolah menengah pertama. Materi ini merupakan materi pembuka bagi Siswa yang ada di kelas VII. Materi pada bab ini terbagi menjadi beberapa macam yaitu bilangan bulat dan bilangan pecahan. Pada materi bilangan pecahan ini masih banyak dijumpai siswa yang kesulitan salah satunya yang terjadi di SMP Islam Zainal Abidin. Siswa yang ada di kelas VII pada SMP I Zainal Abidin belum bisa membandingkan pecahan senilai dan operasi hitung pada pecahan. Hal ini dapat dibuktikan pada saat siswa diberikan pre test dengan tujuan untuk mengukur pemahaman Siswa pada materi tersebut.

\section{METODE}

Penelitian ini dapat digolongkan dalam penelitian pengembangan yang berfokus untuk menghasilkan sebuah karya inovasi yang dapat membantu siswa dan guru dalam suatu proses belajar mengajar serta dapat membuat siswa memahami apa yang telah disampaikan oleh guru. Penelitian pengembangan ini dimodifikasi menurut Borg dan Gall, pada penelitian ini dikembangkan suatu bahan ajar berupa kartu yang dapat dimainkan oleh Siswa kelas VII semester I. Penelitian ini menghasilkan suatu produk yang dinamakan Smart Card yaitu suatu permainan yang dapat digunakan pada materi pecahan.

Penelitian ini menggunakan angket validasi materi dan validasi media serta angket kepraktisan sebagai teknik pengumpulan data. Angket kepraktisan 
digunakan sebagai alat ukur untuk mengukur kepraktisan media yag di peroleh. Data hasil uji validasi materi dan media berupa data kuantitatif. Penilaian kuantitatif terbagi menjadi 5 dengan skala yaitu sangat baik, baik, cukup, kurang, dan sangat kurang. Angket yang telah terisi di hitung dengan memakai rumus.

Keterangan:

$$
P(s)=\frac{S}{N} \times 100 \%
$$

$\begin{array}{ll}\mathrm{P}(\mathrm{s}) & =\text { persentase variable } \\ \mathrm{S} & =\text { jumlah skor tiap variable } \\ \mathrm{N} & =\text { jumlah skor maksimum }\end{array}$

Persentase hasil penelitian kemudian dikategorikan berdasarkan kriteria yang terdapat pada table berikut.

TABEL 1 Kategori kriteria Penilaian

\begin{tabular}{lcc}
\hline No & Interval & Kriteria Penilaian \\
\hline 1 & $81 \% \leq$ skor $\leq 100 \%$ & Sangat Baik \\
2 & $61 \% \leq$ skor $\leq 80 \%$ & Baik \\
3 & $41 \% \leq$ skor $\leq 60 \%$ & Cukup \\
4 & $21 \% \leq$ skor $\leq 40 \%$ & Kurang \\
\hline
\end{tabular}

Untuk mengetahui keefektifan media pembelajaran yang telah dirancang menggunakan pretest dan posstest. Uji keefektifan menggunakan uji beda rerata. Guna menentukan uji beda rerata, terlebih dahulu dilakukan uji normalitas dengan Kolmogorov. Jika uji normalitas terpenuhi maka dilakukan uji beda rerata menggunakan pair t-test, jika tidak terpenuhi menggunakan uji nonparametrik menggunakan Wilcoxon.

Hasil dari lembar pendapat siswa digunakan untuk mengetahui respon siswa terhadap media pembelajaran yang dikembangkan. Hipotesis dari penelitian ini adalah terwujudnya media pembelajaran yang valid, praktis, dan efektif. Media pembelajaran dapat dikatakan valid dan praktis apabila hasil penilaian dari validator minimal $61 \%$ dan termasuk dalam kategori baik. Media dapat dikatakan efektif apabila terdapat perbedaan yang signifikan antara rerata pretest dan posstest dengan nilai posstest lebih tinggi dibandingkan nilai prestest.

\section{HASIL DAN PEMBAHASAN}

Secara manual pembuatan kartu Smart Card ini tidak dapat dikatakan mudah. Karya Inovasi ini memiliki sedikit kesulitan dalam pembuatan desain. Desain dan warna yang menari pada kartu Smart Card ini dapat menarik perhatian Siswa untuk memainkan permainan ini. Media ajar Smart card ini dibuat dengan menggunakan kertas bufallo yang memiliki ketebalan dan warna yang menarik. Karya yang saya buat ini saya terapkan pada materi perbandingan pecahan senilai. 

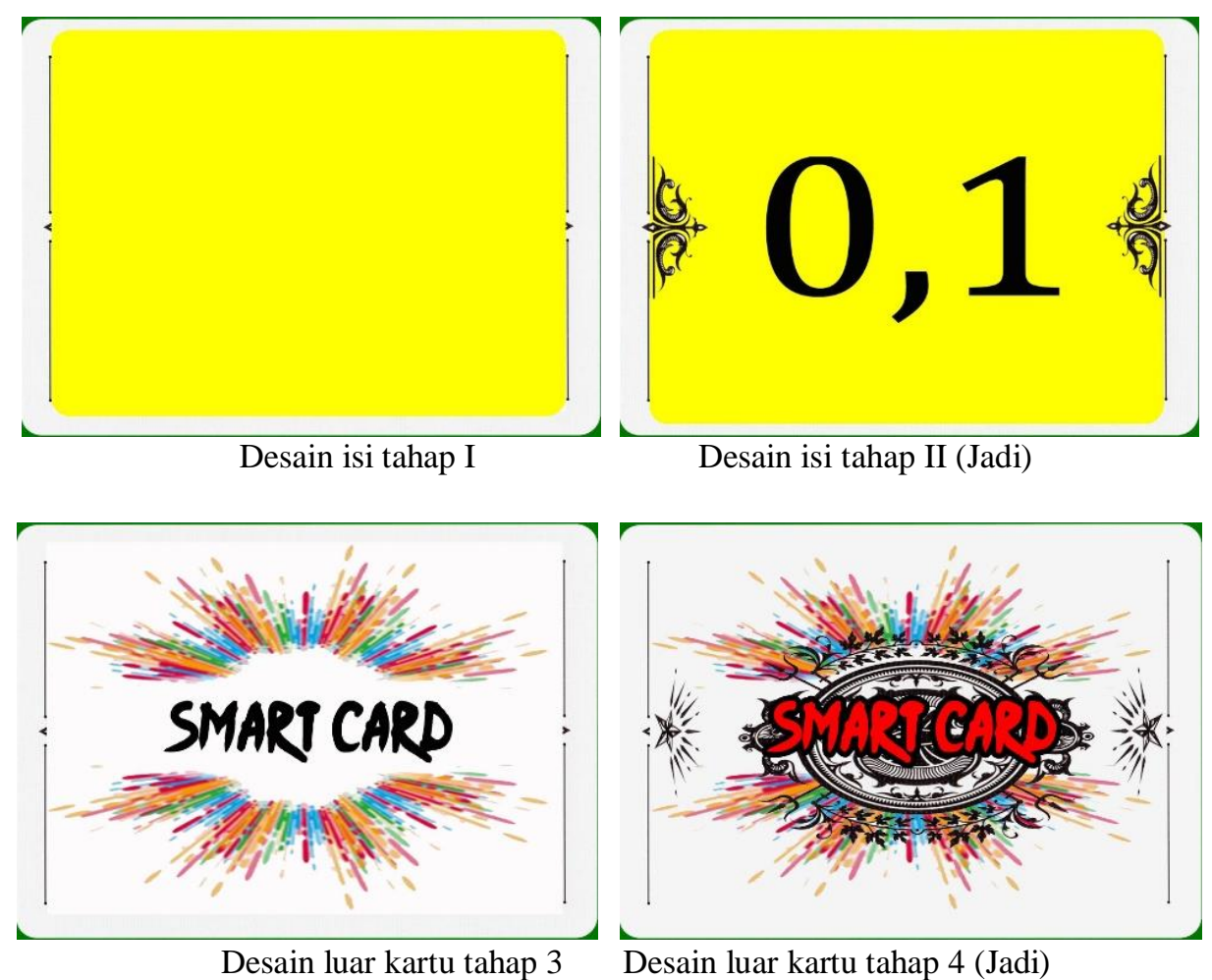

GAMBAR 1 Desain Kartu Smart Card

Cara penggunaan Smart Card ini yaitu: 1) Bentuk kelompok pemain yang terdiri dari 4 orang, 2) Kartu di kocok dan kemudian dibagikan kesetiap pemain, 3) Pemain yang mendapat giliran mengocok kartu mempunyai kesempatan untuk menaruh kartu pertama telebih dahulu, dan 4) Pemain yang lain mencocokkan dengan kartu yang sudah di keluarkan oleh pemain lain, apabila kartu yang dikeluarkan senilai dengan kartu yang ada di tangan maka pemain tersebut mengeluarkan kartu yang senilai dengan yang ada di tangan serta pemain tersebut mengeluarkan kartu sembarang dari tangan, dan 5) kemudian dilanjutkan sampai salah kartu smart card habis.

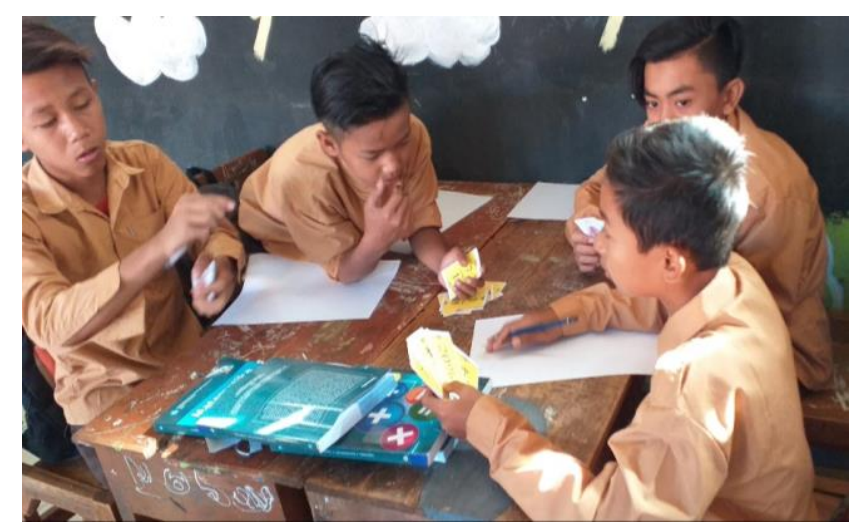

GAMBAR 2 Aplikasi Smart Card 
Smart card ini dapat dijadikan sebagai alat peraga/media pembelajaran di kelas untuk membantu pemahaman siswa pada materi perbandingan pecahan senilai. Seperti kebanyakan kartu lainnya, media belajar ini dapat digunakan dalam pembelajaran dengan menggunakan metode permainan seperti permainan kartu UNO.

Siswa secara keseluruhan sangat menyukai berbagai macam permainan dalam prose pembelajaran. Smart Card yang diterapkan dalam proses pembelajaran memiliki manfaat untuk meningkatkan pemahaman dan keaktifan siswa dalam pembelajaran [9]. Pembelajaran dengan menggunakan alat peraga Smart card di padukan dengan metode permainan $U N O$ dikemas menjadi pembelajaran yang aktif sehinga Siswa merasa tertantang dan termotivasi.

Untuk membuat pembelajaran yang interaktif, inspiratif, menyenangkan, menantang, memotivasi Siswa Smart card di sesuaikan dengan materi dan kebutuhan sekolah. Media ini tidak memerlukan listrik ataupun alat elektronik yang serba canggih. Jadi media ini dapat digunakan oleh sekolah yang minim dalam hal teknologi seperti di SMPI Zainal Abidin. Media belajar berupa Smartcard ini belum terlalu di kenal di sekolah-sekolah, terlebih di sekolah yang ada di lingkungan Kecamatan Sumberasih. Revisi dan potensi Samart Card untuk dikembangkan sangat tinggi. Serta penggunaannya tidak terbatas pada materi perbandingan pecahan senilai saja tetapi dapat diterapkan pada materi lainnya.

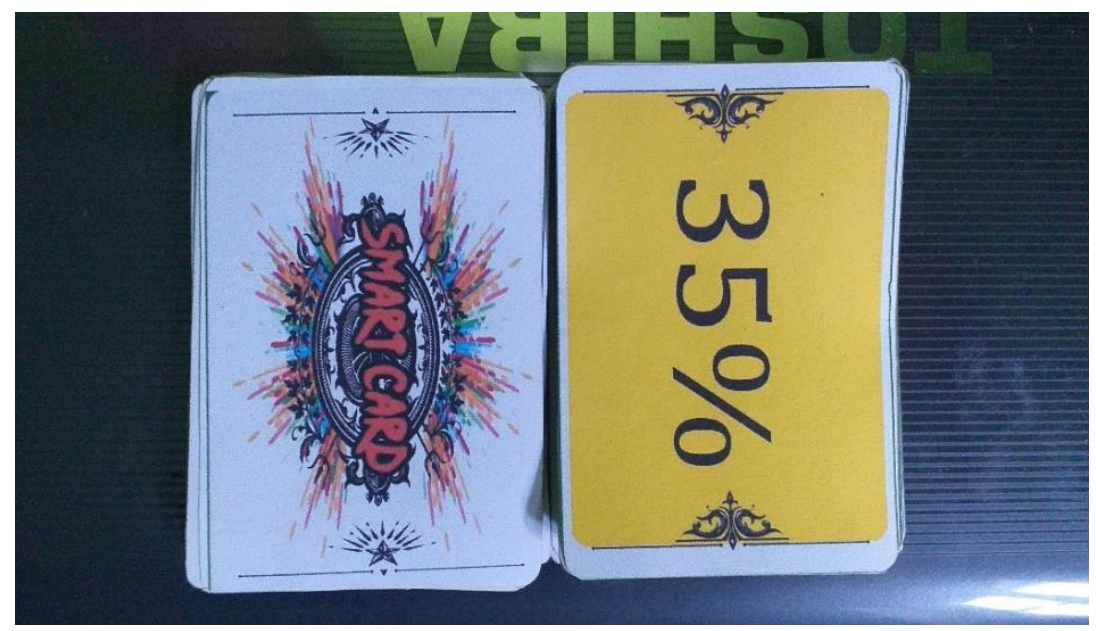

GAMBAR 3 Kartu Smart Card yang Telah Di Potong

\section{Data Hasil Aplikasi Praktis Smart Card}

Ada beberapa hal yang perlu diterapkan dalam penggunaan media ini diantaranya:

1. Tujuan yang hendak dicapai

Dalam penggunaan alat peraga Smart Card ini tujuan yang hendak dicapai adalah, agar Siswa lebih cepat mengerti arti dan makna bilangan pecahan terutama dalam menentukan pecahan senilai.

2. Siapa yang menggunakan/memainkan media Smart Card?

Smart Card digunakan dan dimainkan oleh Siswa sementara Guru hanya memantau dan mengawasi Siswa.

3. Siswa mana yang dikenai permainan Smart Card ini? 
Siswa yang menjadi sasaran penggunaan media Smart Card ini adalah Siswa yang ada di kelas VII semester I SMPI Zainal Abidin yang bertempat di Dusun Blobo Desa Banjarsari Kecamatan Sumberasih Kabupaten Probolinggo.

4. Bagaimana cara penggunaan media ini?

Permainan Smart Card ini penggunaannya sangatlah mudah, dan cara membuatnya juga mudah, apalagi bahannya terbuat dari kertas buffalo yang harganya relative terjangkau.

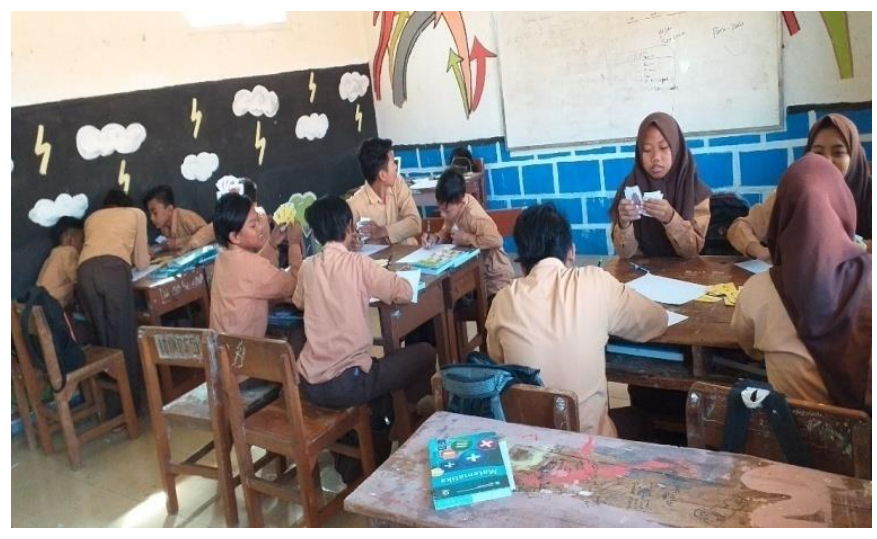

GAMBAR 4 Penerapan Smart Card dalam Materi Pecahan Senilai

Pada penggunaan media pembelajaran Samrt Card ini dijumpai beberapa hal yang ini diantaranya yaitu para Siswa menikmati permainan ini sehingga proses belajar mengajar yang terjadi di dalam kelas lebih aktif dan menyenangkan dari pada biasanya.

\section{Analisis Data Hasil Penggunaan Media Smart Card dalam Pembelajaran}

1. Deskripsi hasil pengamatan

Dari hasil pengamatan dapat dikatakan bahwa Siswasangat semangat, senang, dan termotivasi dalam permainan Smart Card.

2. Data nilai hasil belajar

Penggunaan Smart card ini dapat membantu siswa dalam memahami materi pecahan senilai serta dapat pula meningkatkan hasil pembelajaran siswa. Hal ini dapat dibuktikan dari hasil pembelajaran siswa sebelum menggunakan permainan Smart Card yaitu 58,33 sedangkan setelah penggunaan media pembelajaran Smart Card sebesar 77,92.

3. Pembahasan hasil pengamatan proses serta hasil belajar Siswa.

Penggunaan media pembelajaran ini ternyata memeberikan dampak positif bagi Siswa dalam mengikuti pembelajaran. Berbeda jika pembelajaran hanya menggunakan metodeceramah dan teori-teori dari buku.

4. Refleksi pengunaan karya inovasi

Melalui karya inovasi yang diterapkan oleh Guru, secara pribadi Guru dapat menyampaikan pesan-pesan pembelajaran secara utuh tanpa menggunakan metode ceramah. Bagi Guru yang lain dapatmemeberikan contoh sehingga proses pembelajaran yang terjadi didalam kelas menjadi lebih hidup. 
Bagi Siswa pembelajaran menjadi lebih menyenangkan, aktif dan kreatif. Penerapan Media Pembelajaran Smart Card ini dapat dipergunakan oleh siapa saja dalam melakukan proses belajar mengajar di dalam kelas maupun secara mandiri yang dimainkan di rumah oleh siswa. Pada karya inovasi ini perlu dilakukan uji coba lebih luas dan dilanjutkan pemaketan akhir dengan pemilihan distributor, pengesahanhak cipta, dan disebarkan luaskan sehingga dapat dipergunakan oleh kalangan luas.

Bagi guru atau peneliti serta pengembang selanjutnya dapat mengembangkan media ini dengan beberapa modifikasi yang lebih baik dari sebelumnya, seperti: (a) penambahan kartu soal yang lebih bervariasi dan memiliki tahap kesulitan yang berbeda, (b) pembuatan desain yang lebih bagus dari sebelumnya, (c) penggunaan kertas yang sama dengan kertas yang dipakai untuk membuat kartu bridge atau kartu UNO yang ada dipasaran, dan (d) peraturan yang digunakan di ketik dan di print sebagai acuan permainan dari kartu Smart Card.

\section{KESIMPULAN}

Secara keseluruhan permainan Smart Card ini dapat disimpulkan memiliki sedikit kesulitan dalam hal pembuatan desain yang mana desain harus di buat memiliki 2 bentuk yaitu desain dalam dan desain luar. Media ini tidak memerlukan penggunaan listrik sehingga dapat dimainkan dimanapun dan kapanpun tanpa mengkhawatirkan sumber daya listrik. Media ini berupa permainan sehingga siswa merasa bersemangat, senang, dan termotivasi ketika pembelajaran berlangsung. Selain itu guru dapat memberikan pembelajaran secara aktif dan langsung sehingga membuat siswa tertarik, tertantang, dan termotivasi pada permainan Smart Card ketika proses pembelajaran berlangsung. Pembelajaran yang dapat dimainkan membuat suasana di dalam kelas aktif serta tidak membuat siswa merasa jenuh, hal ini memberikan dampak positif kepada siswa yaitu selain siswa memiliki pemahaman yang lebih tinggi siswa juga memperoleh hasil belajar yang lebih tinggi dari pada sebelumnya.

\section{DAFTAR RUJUKAN}

[1] Anam, M.K. 2017. Analisis Pemahaman Konsep Siswa Kelas VIII Pada Materi Teorema Pythagoras. Seminar Nasionas Guruan Matematika UMM Malang, 31 Agustus 2017. Prosiding ISSN :2528-4460.

[2] Undang-undang No. 23 Tahun 2003.

[3] Hamalik, O. 1999. Media Guruan. Bandung : Citra Aditya Bakti.

[4] Sudirman, A. Media Guruan. Rajawali Press, 2012.

[5] Tim Penyusun Kamus Besar Bahasa Indonesia. 1998. Kamus Besar Bahasa Indonesia. Jakarta : Balai Pustaka.

[6] Rahadi, A. 2003. Media Pembelajaran. Jakarta: Departemen Guruan Nasional.

[7] Rahwanti, Juni dkk. (2017). Pengembangan Media Pembelajaran Uno Statik dalam Penerapan Model Pembelajaran Snowball Throwing Materi Turunan Kelas XI. Seminar Nasional Pendidikan, Sains dan Teknologi FMIPA: Universitas Muhammadiyah Semarang.

[8] Rahwanti, R dkk. (2018). Peran Permainan Kartu UNO Dalam Meningkatkan Ketrampilan Berpikir Kritis Siswa. Jurnal Program Studi Pendidikan Biologi. Volume 9, Nomor 2, UIN Malang Agustus 2018. e- ISSN 2615-0417.

[9] Sriyati, Suci Rahmadhiana. (2016). Modifikasi Permainan UNO Sebagai Alternatif Bahan Pembelajaran Penjumlahan dan Pengurangan Bagi Siswa Kelas 1 Sekolah Dasar. Kalimaya, Volume 4, Nomor 2, Agustus 2016. 